\title{
GOVERNMENT SUPPORT FOR THE DEVELOPING ENTREPRENEURSHIP IN SWITZERLAND AND RUSSIA WITH EMPHASIS ON FORESTRY AND FOREST-BASED INDUSTRIES
}

The paper presents an analysis of current practice implementation of government support measures for developing entrepreneurship in Switzerland and Russia, with special emphasis on the forestry and forest-based industries. The aim of it is to identify the most urgent and effective measures of government support for encouraging innovation and developing entrepreneurship.

The authors analyze the financial, administrative, educational and legal aspects in the development of modern business. They investigate the specifics of the application development mechanisms Enterprise Institute depending on the type of economy. Particular emphasis is placed on the analysis of enterprises innovative activities and their roles in the development of the modern Entrepreneurship Institute. Also, they investigate the wide range of instruments of governmental support, which are provided at the regional level.

The comparison and analysis have resulted to making proposals for optimization of the Russian government support programs for entrepreneurship on state-and regional levels. The results of the comparison can be useful to improve developing entrepreneurship and encouraging innovation in the forestry and forest-based sector at the regional policy of Russia.

Keywords: government support measures, innovation, entrepreneurship, forestry and forest-based industries

\section{Introduction}

Nowadays the role of entrepreneurship in the economic development of any country is increasingly important. The significance of this phenomenon is confirmed by the fact that major international organizations such as UN, EBRD, IFC, and
TACIS as well as different state and regional establishments have a deal with the developing small and medium-sized businesses.

In most cases, entrepreneurship refers to the establishing a new business or enterprise (self-employment, a new business entity, the expansion of 
an existing business), undertaken by an individual, group of individuals or within existing companies [1].

According to statistics published by the International Trade Centre (UNCTAD / WTO) the percentage share of GDP for small and medium-sized enterprises in developed countries including Switzerland equals $60-70 \%$, the percentage share of export for small and medium-sized businesses equals 75-80\% [2]. We'd like to underline so high shares are provided by small and medium-sized businesses being the backbone of the Entrepreneurship Institute.

It is known wood is one of the most significant renewable natural resources used as raw material for manufacturing more than 5000 products. Forests meet different needs providing us with not only timber and other raw materials for industry but major socially beneficial functions vital to life. It is the reason why sustainable forest management and advanced wood technologies can be considered as economic potential and therefore they are strategic for local sustainable development especially for rural areas.

The basis of the economic well-being in many countries is based on the sustainable management of forest resources. For example, Finland is one of the most innovative countries; it is included into top 10 leaders in the Global Innovation Index [3], its economic has been developed on the base of the sustainable forestry and forest-based industries recognized for green innovations.

In the world, there are different kinds for government support for developing entrepreneurship in the forestry and forest-based sector: direct budgetary allocation to investment funds, venture capital funds, mixed funds support - public and private, loan guarantees and loans of commercial banks - guarantees to compensate the bank for losses, tax benefits. However, there is no any universal model of government assistance to support entrepreneurship in forestry and forest-based industries which can guarantee achieving high economic development indicators because the best model of government support for entrepreneurship is unique for each separate economy in the world.

Nevertheless we find while developing the national integrated approach to government assistance to support Russian forestry and forest-based sector our country can benefit from learning the successful experiences of countries having achieved high levels of economic development. It is no doubt one of such countries is Switzerland.

\section{Theoretical basis of the research}

It is known fact the economies of Russia and Switzerland refer to different types. Switzerland belongs to group of innovation-based economies with a special focus on high value added products using state-of-the art technologies to be competitive in the world. Russia belongs to a group of countries focusing on efficiency-based economies, where the main strategic goal is to increase the productivity of enterprises [4].

The main macroeconomic indicators in the Russian Federation up to 2020 are expected to be based mainly on innovation implementation in socio-economic development [5]. Therefore, learning the experience of the country having of an innovation-based economy is useful for the programme execution and the achieving indicators planned in "Strategy 2020".

Switzerland has an innovation-based economy so entrepreneurship policy framework is getting more important driver for economic growth than basic framework or economic effectiveness. According to the «Report on International Competitiveness, 2009-2010» Switzerland took the first place among 133 countries considered in this study [6].

Switzerland is the first country not because of the only the overall assessment, but also with the eight indicators within five categories such as «Institutions», «Infrastructure», «Health», «General education and professional development» and «Innovation».

Switzerland provided the most number of Nobel Prize winners in sciences per total number of inhabitants; it has the most number of patents per 1000 inhabitants in the world. It has a well-developed system of intellectual property protection. The Swiss Institute of It is known fact the economies of Russia and Switzerland refer to different types. Switzerland belongs to group of innovation-based economies with a special focus on high value added products using state-of-the art technologies to be competitive in the world. Russia belongs to a group of countries focusing on efficiency-based economies, where the main strategic goal is to increase the productivity of enterprises [4].

The main macroeconomic indicators in the Russian Federation up to 2020 are expected to be based mainly on innovation implementation in socio-economic development [5]. Therefore, learning experience of the country having of an innovation-based economy is useful for the program execution and the achieving indicators planned in "Strategy 2020".

Switzerland has an innovation-based economy, so entrepreneurship policy framework is get- 
Types of economies

\begin{tabular}{|l|l|}
\hline \multirow{4}{*}{$\begin{array}{l}\text { Innovation-based } \\
\text { countries }\end{array}$} & $\begin{array}{l}\text { Australia, Belgium, Britain, Germany, Holland, Denmark, Greece, Ireland, Israel, Iceland, Ireland, Italy, } \\
\text { Norway, Portugal, Republic of Korea, Slovenia, the USA, Finland, France, Switzerland, Sweden, Japan }\end{array}$ \\
\cline { 2 - 3 } $\begin{array}{l}\text { The economy needs to produce innovative products. } \\
\text { Using sophisticated methods of production (ICT), firm able to survive if it competes on the basis of } \\
\text { innovation }\end{array}$ \\
\hline \multirow{3}{*}{$\begin{array}{l}\text { Efficiency-based } \\
\text { Reuntries } \\
\text { countries }\end{array}$} & $\begin{array}{l}\text { Argentina, Bosnia and Herzegovina, Brazil, Hungary, China, Colombia, Costa Rica, Latvia, Macedonia, } \\
\text { Malaysia, Mexico, Montenegro, Peru, Russia, Romania, Taiwan, Tunisia, Turkey, Croatia }\end{array}$ \\
\cline { 2 - 3 } & $\begin{array}{l}\text { Efficient production to increase performance. Competitiveness is achieved as a result of higher education, } \\
\text { market efficiency and the ability to benefit from existing technologies }\end{array}$ \\
\hline & $\begin{array}{l}\text { Angola, Bolivia, Vanuatu, Ghana, Guatemala, Egypt, Zambia, Iran, Pakistan, Saudi Arabia, the Gaza Strip, } \\
\text { Uganda, Jamaica }\end{array}$ \\
\cline { 2 - 3 } & $\begin{array}{l}\text { Firms compete on price, use the basic factors of production, primarily unskilled labor and natural } \\
\text { resources }\end{array}$ \\
\hline
\end{tabular}

ting more important driver for economic growth than basic framework or economic effectiveness. According to the «Report on International Competitiveness, 2009 - 2010» Switzerland took the first place among 133 countries considered in this study [6].

Switzerland is the first country, not because of only the overall assessment, but also with the eight indicators within five categories such as «Institutions», «Infrastructure», «Health», «General education and professional development» and «Innovation».

Switzerland provided most number of Nobel Prize winners in sciences per total number of inhabitants; it has the most number of patents per 1000 inhabitants in the world. It has a well-developed system of intellectual property protection. The Swiss Institute of Intellectual Property integrates the protective measures for patents, trademark, design and copyright, thus providing protection of innovation and creativity within the country and abroad. The World Intellectual Property Organization is located in Geneva.

Confederation and regional-level schools and universities led by the Federal Polytechnic Universities in Zurich and Lausanne develop many new technologies, and have specific programs to carry innovations into new enterprises. In addition, the world-renowned International Institute for Leadership Development (IMD) in Lausanne provides high-level executive training, including the techniques for encouraging innovations and new business development. Leading firms in areas such as pharmaceuticals, biotechnology, medical technology and information technology, have placed their research laboratories in Switzerland in order to use excellent opportunities presented there to promote the scientific and technological progress. There are several Swiss industry-specific “clusters'.
However, we should notice government support for entrepreneurship in forestry and forest-based industries in Switzerland is not such high-developed as for the above mentioned areas. In fact, there is a strong case for saying that in this field Switzerland has more to learn from Russia than the other way round.copyright, thus providing protection of innovation and creativity within the country and abroad. The World Intellectual Property Organization is located in Geneva as well as.

Cconfederation and regional-level schools and universities led by the Federal Polytechnic Universities in Zurich and Lausanne develop many new technologies, and have specific programmes to carry innovations into new enterprises. In addition the world-renowned International Institute for Leadership Development (IMD) in Lausanne provides high-level executive training, including the techniques for encouraging innovations and new business development. Leading firms in areas such as pharmaceuticals, biotechnology, medical technology and information technology, have placed their research laboratories in Switzerland in order to use excellent opportunities presented there to promote the scientific and technological progress. There are several Swiss industry-specific "clusters'.

However we should notice government support for entrepreneurship in forestry and forest-based industries in Switzerland is not such high-developed as for the above mentioned areas. In fact, there is a strong case for saying that in this field Switzerland has more to learn from Russia than the other way round.

Nevertheless, the favorable business climate in Switzerland extends to forestry and wood-based products. There is even a degree of "come-back" for wood, both for fuel and as an essential part for sustainable living, a subject for which an entirely 
new Technopark is being created in Fribourg, linked to the Lausanne Polytechnic University.

The Swiss tax system is flexible and efficient and involves competition amongst cantons. The total tax burden is moderate by the standards of developed countries. The system reflects the country's federal structure: taxes are collected by the federal government, the cantons, and municipalities. The federal income tax is usually 8.5\% [7], but the largest amount of tax is paid at the communal and cantonal level. Thus, the total tax burden as a percentage of income in Switzerland is 28.9\% (compare in Russia 48.7\% [8]). The difference between tax burdens is more than $70 \%$; this fact shows we should implement programmes to support entrepreneurship and optimize tax burden in Russia.

Investment projects that create a great number of jobs in Switzerland can be partially exempted of tax. Switzerland has signed double taxation agreements with all of the major industrialized countries and a number of other states. Switzerland has a tradition of relatively benevolent and constructive relationship between the tax payers and tax authorities.

The procedure for company registration in Switzerland is simple and rapid: as a rule the documents fulfilling before the legal instances take two or four weeks. Freedom of occupation, trade and commerce allows, in principle, any person to run a business, register it or participate in it. Mandatory requirement is one of those who has right of signature in a company must be resident of Switzerland. In contrast to the registration of companies, their liquidation is extremely numerous and slow.

Commercial law has a relatively moderate degree of regulation. When choosing a legal form (mainly open joint stock company vs. closed), as well as details of the organizational structure of a company, there are a number of options. Financial reports may be submitted by any internationally accepted rules [7].

Thus, we can conclude Switzerland created favorable conditions for the development and running businesses: there have developed all the advanced business systems, reduced administrative barriers and minimized the tax burden.

At the same time, nowadays in Russia there are high administrative barriers for entrepreneurs and high tax burden (more than 70\%). Since the country belongs to the efficiency-driven countries, the main policy attention is paid to the development of entrepreneurship based on natural resources.

Most of the small enterprises in the forestry and forest-based sector in the Russian economy emerged in the wake of massive bankruptcies of forest-based enterprises in 1995-1998. Many small businesses and new jobs were established on the base of the liquidated or reformed enterprises. Forestry and forest-based industries contribute to a comprehensive range of small-sized business development, a feature, which is not only addressed economic and but also social objectives, such as supplying regional markets with consumer goods, employment, as well as the creation of additional social infrastructure and so on. Forestry also has an environmental-forming function improving the forests, reducing forest fire risk, increasing their protective functions and providing a healthy environment.

The above mentioned features of entrepreneurship in the forestry and forest-based industries are taken into account in public policy. It is the reason why state structures, public bodies have high interest towards the forestry and forest-based industries in terms of industrial policy in the industry. We find this is an extremely positive fact [9]. This demonstrates that the state tries to improve management of natural resources, but also to develop the favorable business climate in the forestry and forest-based industries in the country. It is a field where Russia has a significant competitive benefit from natural and climatic conditions. The main policy purpose is to encourage high investment and innovation activities by the internal and external potential investors.

Analysts of the rating agency «Expert RA» believe that the policy of institutional changes in the forestry and forest-based industries up to 2015 will be aimed at increasing the number of effective owners who are interested in the long-term development of enterprises. In addition, the number of state enterprises should be changed through privatization and the integration of enterprises via the establishment of large industrial structures, and the elimination of unprofitable and unpromising businesses [9].

In the framework of the policy the following main areas of institutional changes are offered:

- The number of state unitary enterprises should decrease significantly to reach 100 units by 2015;

- The number of joint-stock companies with state share will be reduced to about 300 ;

- To encourage investment to the forest-based industries it is planned to place of shares of open joint-stock companies in the secondary securities markets and open access to international financial markets;

- To ensure sustainable supply of wood raw materials for wood-based enterprises it will be 
continued establishing a system of vertically integrated companies which will cover the whole production cycle, from harvesting to manufacturing and marketing of the final product. Number of integrated and combined businesses can achieve $70 \%$ of the total number of enterprises in the industry by 2015 ;

- One of the main areas of institutional change in the future will be to support small-sized businesses.

When we implement basic measures to support developing entrepreneurship and the small and medium-sized forest enterprises perform in an effective way, the next challenge we'll face will be the creating of a favorable business climate. Then, the Swiss experience in encouraging innovation and entrepreneurship in a wide range of hi-tech industries will be very useful to study for Russia.

\section{Data of Entrepreneurship}

The performance of the governmental measures to support developing business can be measured by the level of entrepreneurial activity achieved as a result of the policy implementation. Entrepreneurial activity in general for Russia and Switzerland in 2009-2011 was characterized by the data presented in Table 2 [10]. Indicators of business activity are higher almost twice in Switzerland in comparison with Russia; however at the same time in Russia there is a tendency of growth of Russian entrepreneurs' activity in spite of the global economic crisis while the tendency is reversed in Switzerland.

One of the bases for the high level of business activity in Switzerland is a highly productive intensive agriculture including forestry.
There are about 4 million employees (57\% of the population), including in agriculture and forestry $-4.1 \%$ in Switzerland. Forests cover more than $30 \%$ areas in the country [11], compare, forests - the main type of vegetation in Russia, they occupy $45 \%$ of the territory. [13]. But the functions of the forests in Switzerland are seen not only as an economic perspective, but much wider. Therefore, the Swiss agriculture, which includes forestry is one of the most subsidized in the world.

According to the Organization for Economic Cooperation and Development (OECD), Switzerland subsidizes more than $70 \%$ of its agriculture, compared with $35 \%$ in the EU [12]. In addition, Swiss agriculture relies on many protectionist barriers.

Despite the significant potential of the industry, the Russian forest sector has not yet taken an important place in either the national economy or global. The contribution of the forestry and forest-based sector in Russia's GDP is more than 1 percent, in foreign currency earnings - nearly 2 percent, in world trade - about 3 percent [13], the figures indicate the low efficiency of the forest resource potential.

Nowadays it is reforming mechanism of the governmental support for forestry and forest-based industries in Russia.

In addition to governmental support for priority investment projects, the federal legislation provides the following measures:

1. Subsidies from the federal budget to Russian industries of agricultural machinery and tractors, forest-based industries, machinery for oil and gas, and the machine-tool industry for reimbursement of the cost of interest on loans received

Table 2

Entrepreneurial activity in Russia and Switzerland in 2009-2011

\begin{tabular}{|c|l|c|c|c|c|c|c|c|c|c|}
\hline \multirow{2}{*}{ № } & \multicolumn{2}{|c|}{ Indicators } & \multicolumn{3}{|c|}{ Russia } & \multicolumn{3}{c|}{ Switzerland } & \multicolumn{3}{c|}{$\begin{array}{c}\text { Deviation } \\
\text { (Russia - Switzerland) }\end{array}$} \\
\cline { 3 - 12 } & & $\mathbf{2 0 0 9}$ & $\mathbf{2 0 1 1}$ & $\Delta$ & $\mathbf{2 0 0 9}$ & $\mathbf{2 0 1 1}$ & $\Delta$ & $\mathbf{2 0 0 9}$ & $\mathbf{2 0 1 1}$ & $\Delta$ \\
\hline 1 & & 3 & 4 & 5 & 6 & 7 & 8 & 9 & 10 & 11 \\
\hline 1 & & & $4-3$ & & & $7-8$ & $3-6$ & $4-7$ & $10-9$ \\
\hline 2 & $\begin{array}{l}\text { Level of nascent } \\
\text { entrepreneurs activity }\end{array}$ & 1.8 & 2.4 & 0.6 & 4.3 & 3.7 & -0.6 & -2.5 & -1.3 & 1.2 \\
\hline 3 & $\begin{array}{l}\text { Level of owners activity of } \\
\text { newly created businesses }\end{array}$ & 2.3 & 2.3 & 0 & 3.5 & 2.9 & -0.6 & -1.2 & -0.6 & 0.6 \\
\hline 4 & $\begin{array}{l}\text { Level index of early-stage } \\
\text { established entrepreneurs }\end{array}$ & 3.9 & 4.6 & 0.7 & 7.7 & 6.6 & -1.1 & -3.8 & -2 & 1.8 \\
\hline 5 & $\begin{array}{l}\text { Level of out coming } \\
\text { businesses }\end{array}$ & 2.2 & 1.5 & -0.7 & 2.1 & 2.9 & 0.8 & 0.1 & -1.4 & -1.5 \\
\hline 6 & Forced entrepreneurs, \% & 29 & 27 & -2 & 7 & 11 & 4 & 22 & 16 & -6 \\
\hline
\end{tabular}


from Russian credit institutions to retool for up to 5 years (Government of the Russian Federation on March 10, 2009 number 205).

2. Subsidies to federal budget entities of the industry for reimbursement of the interest on loans received from Russian credit institutions in 2010-2011 years to make of pre-season stocks of wood, raw materials and fuels (Government of the Russian Federation of 13.05.2010 № 329 (edition 28.12.2010).

3. Subsidies from the federal budget entities in the forestry and forest-based industries for reimbursement of interest on loans obtained in 20122013, respectively, to implement investment projects to start new high-tech manufacturing industries (Government of the Russian Federation of 16.01.2013, the number 2).

A wide range of instruments of governmental support are provided on the regional level. Each region is developing and implementing its own additional measures of governmental support. For example, the Sverdlovsk region exercises the following regional measures of governmental support for entrepreneurship in the forestry and forest-based industries:

1. Support for small and medium-sized enterprises within the framework of the regional target program «Development of small and medium-sized enterprises in the Sverdlovsk region" on the 2011-2015 years", approved by the Government of the Sverdlovsk region 11.10.2010 № 1483-PP:

- Financing of the costs of small and medium-sized enterprises related to the acquisition of equipment for the development and (or) development and (or) the modernization of the production of goods (works, services);

- Subsidies on costs of small and medium-sized enterprises related to the promotion of energy efficiency of production;

- Financing costs of small and medium-sized enterprises for technological connection to electrical grid;

- Financing costs of small and medium-sized businesses to pay the interest on loans obtained in the Russian credit organizations;

- Subsidies for the payment of the first installment under lease agreements entered into by small and medium-sized enterprises in the Sverdlovsk region;

- Subsidies to small and medium-sized enterprises in the Sverdlovsk region, producing and (or) selling goods (works, services) intended for export;

- Support for existing small and medium-sized companies involved in the salons, exhibitions, conferences, trade fairs, «business missions», and other activities related to entering regional and international markets for products, goods and services;

- Provision of preferential investment loans to small-sized businesses in the Sverdlovsk region;

- Subsidies for start-ups and existing smallsized innovative companies in the Sverdlovsk region;

- Reimbursement of the cost of equipment under lease agreements, providing security for bank loans, compensation of expenses for the promotion of export-oriented enterprises, preferential loans.

2. Government guarantees provided by the Sverdlovsk region, subsidies from the regional budget, providing information on issues related to investment activity in the Sverdlovsk region; the information can be found in the documents included in the information systems of public authorities of the Sverdlovsk region, assistance in establishing foreign economic relations, necessary for the implementation of the investment activity in the form of capital investments in the Sverdlovsk region (Article 2 of the Sverdlovsk region of 30.06.2006 № 43-OZ «On state support of investment activity in the Sverdlovsk region»).

Currently under development is the regional target program for the development of the industry and increase of competitiveness in the period of 2014-2018. The programme includes a number of measures to support forestry and forest-based industries in the region: subsidies for compensation for the interest rate on loans for the purchase of equipment, subsidies for reimbursement of costs related to research and development activities, and subsidies for reimbursement of costs associated with the introduction of a new product.

In order to create a favorable investment climate, the Sverdlovsk region is amending the Laws of the Sverdlovsk region «on the income tax rate for individual categories of taxpayers in the Sverdlovsk Region» from November 29, 2002 № 42 $\mathrm{OZ}$ and «On the establishment in the Sverdlovsk region property tax «of 27 November 2003 number $35-\mathrm{oz}$. These proposed laws establish exemptions for income tax and property tax in part and are reflected in the budget of the Sverdlovsk region. They will benefit taxpayers who have the status of members of priority investment projects to modernize the Sverdlovsk region, by reconstruction and technical re-equipment of fixed assets.

\section{Analysis of data entrepreneurs}

The level of business activity indicators in Switzerland is a reference for Russia today. There 


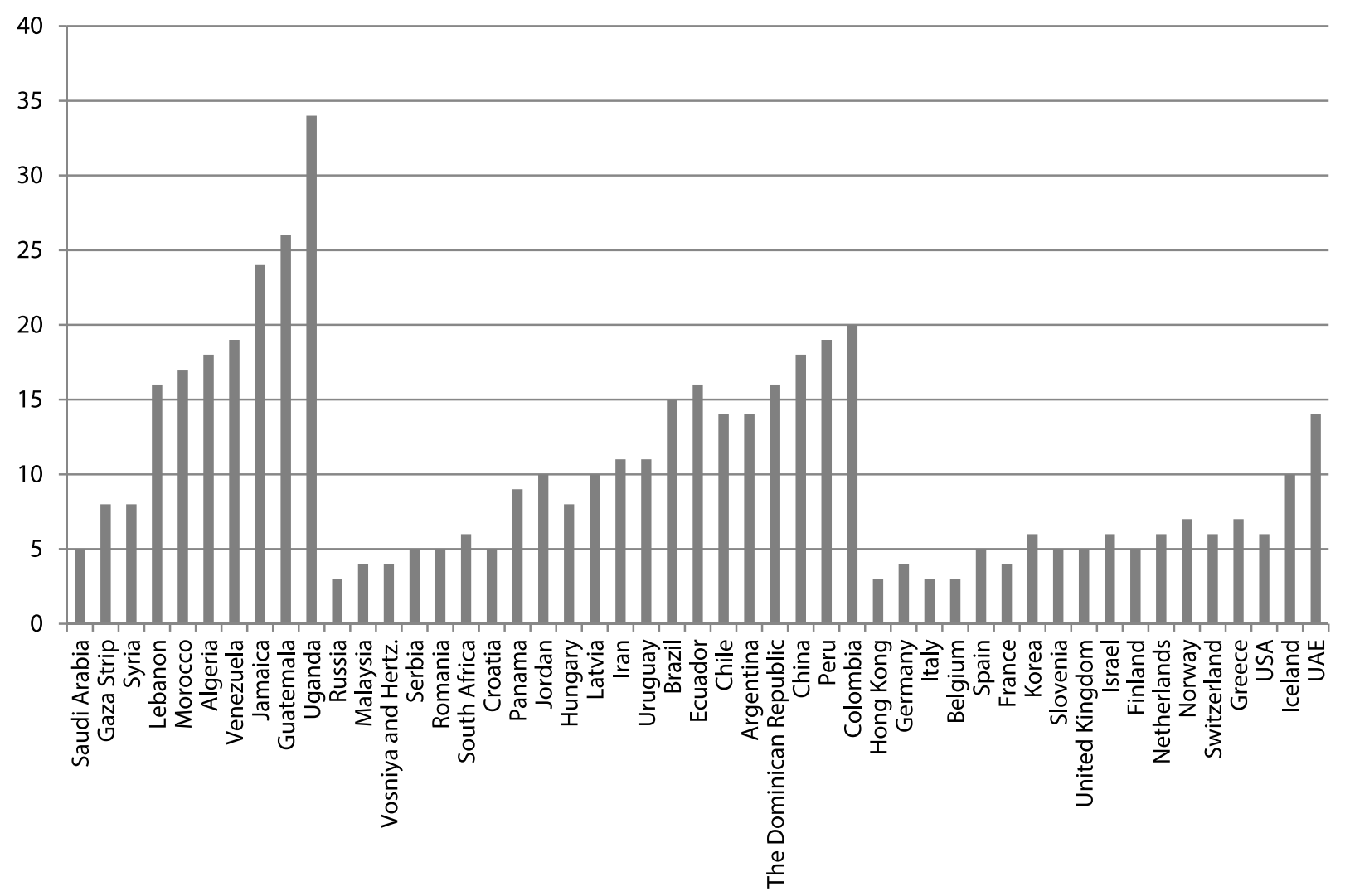

Fig. 1. Indexes of entrepreneurial activity for countries, 2011

is a need to carry out profound structural economic reforms to allow businesses to form a strong component of the economy. Russian experts say that the main factors impeding the development of modern business in Russia are unfavorable so- cio-political situation, the unstable government policies and lack of financial support.

Expert assessment of the availability of finance for entrepreneurial firms in Russia is one of the

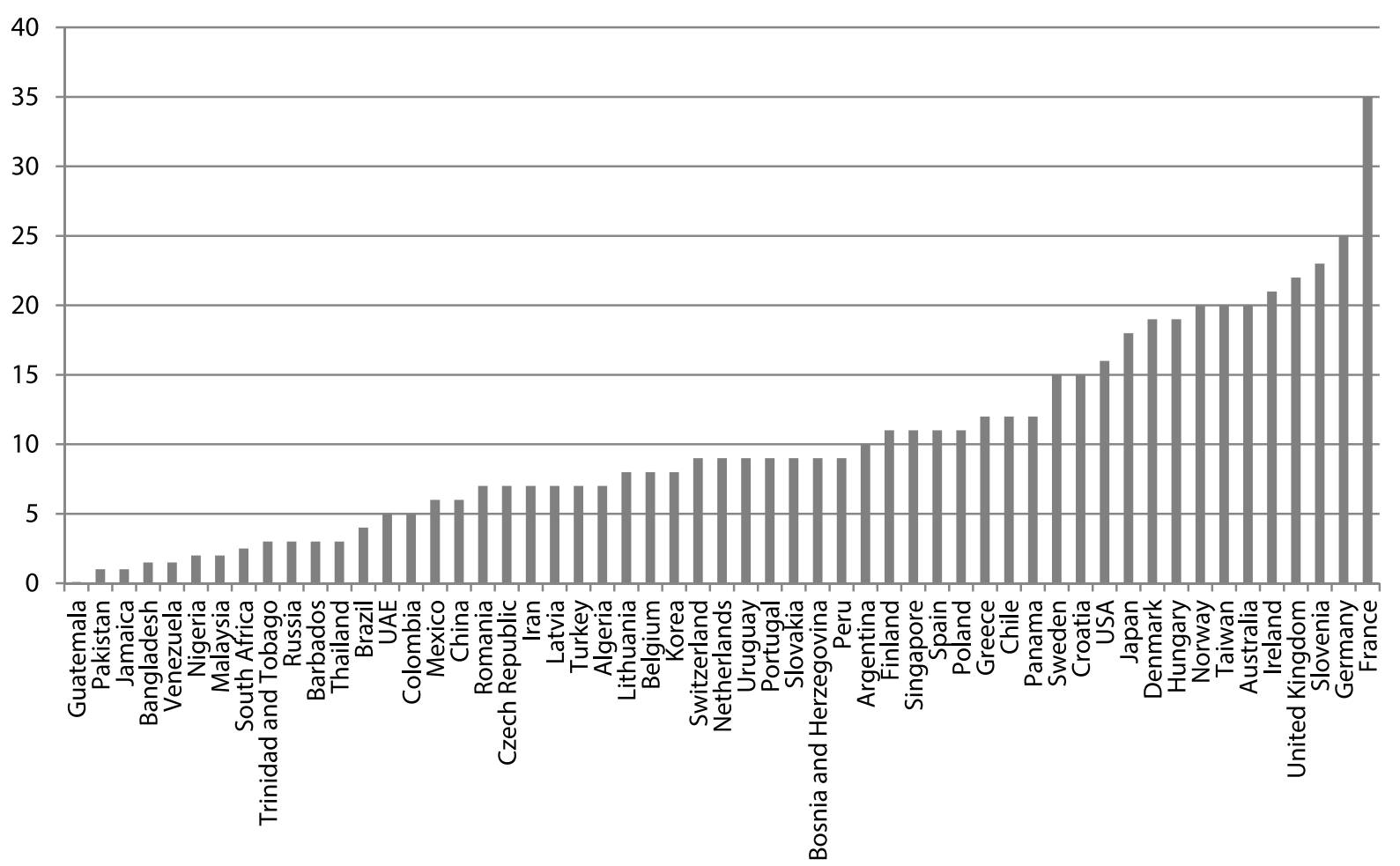

Fig. 2. Entrepreneurs activity in the high-tech sector, 2011, \% 


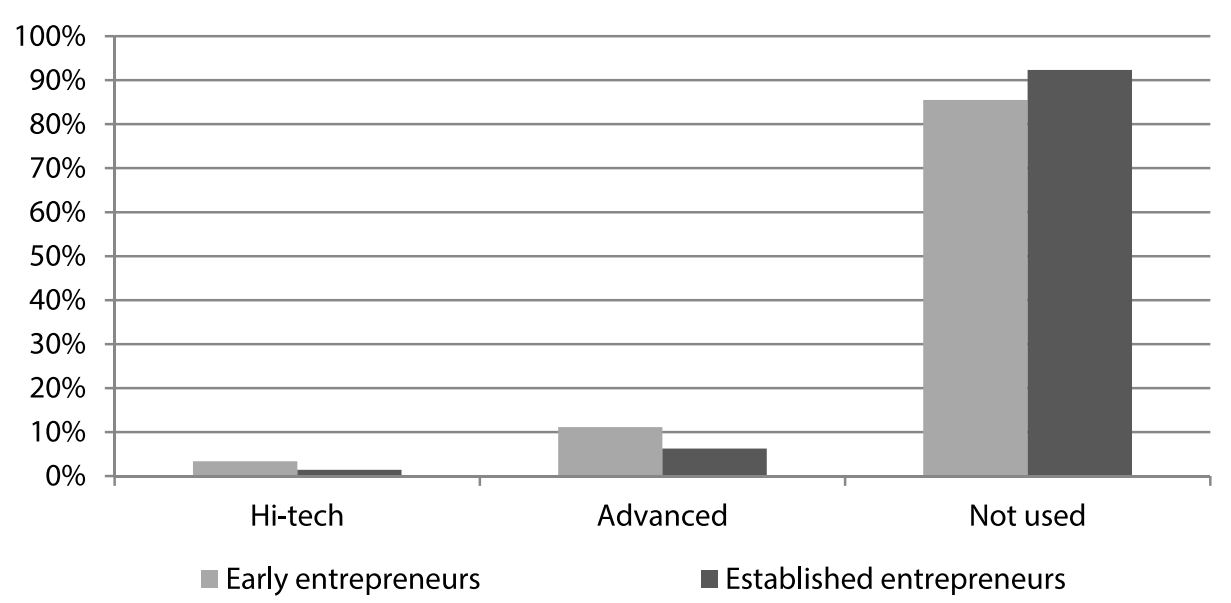

Fig. 3. Using high-tech and advanced technologies by nascent and established entrepreneurs $2011, \%$

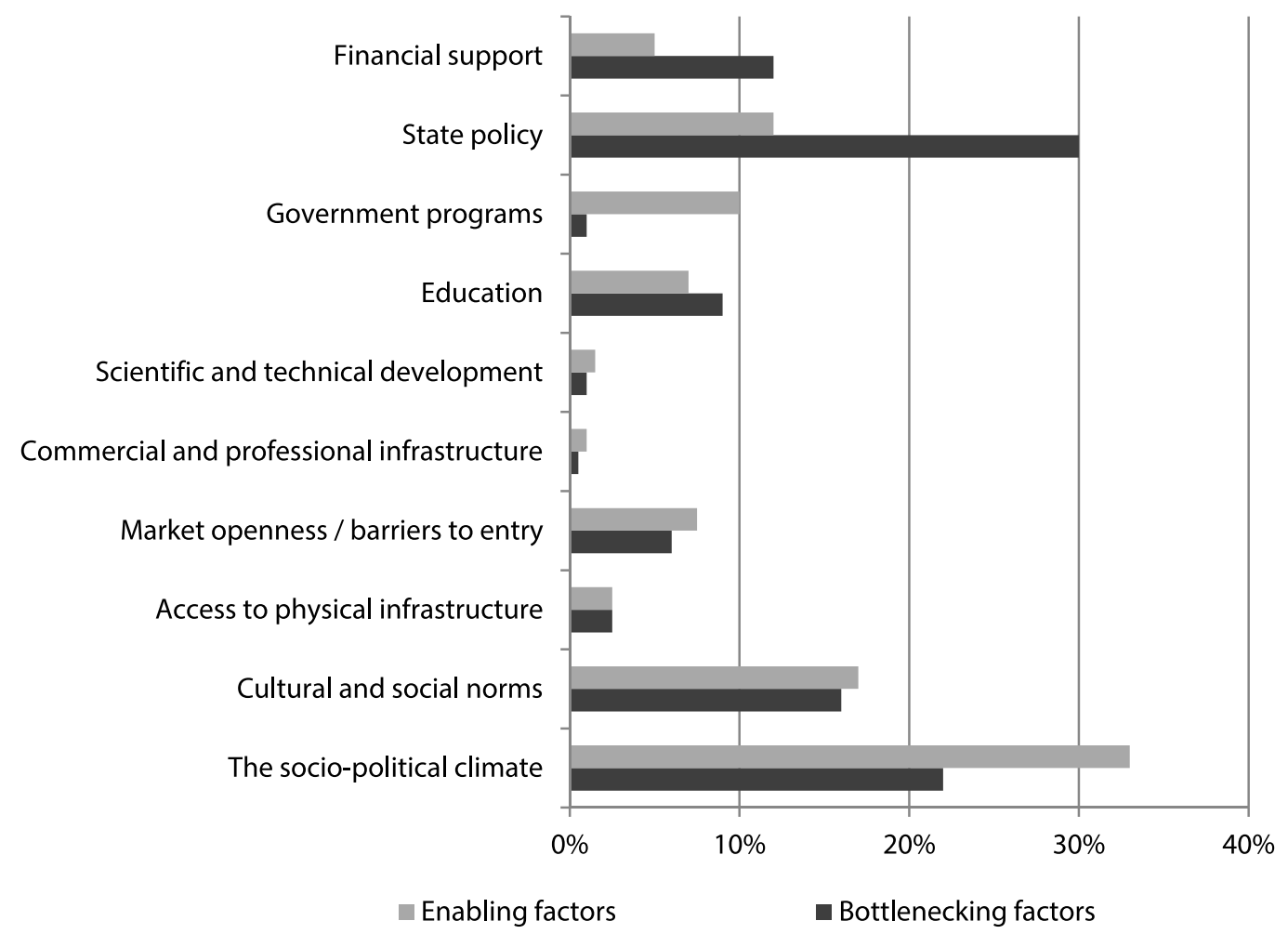

Fig. 4. Assessment of enabling and bottlenecking factors for developing entrepreneurship given by Russian experts, 2011, \%

worst among the majority of developed and developing countries [4].

Indicators of socio-oriented entrepreneurial activities in Russia are lower twice than those in Switzerland and are equal to $5 \%$ and $10 \%$, respectively (Fig. 1) [4].

There are many world-famous foundations and organizations that provide financial and professional assistance to social entrepreneurs, such as Ashoka Foundation, the Foundation Scola, the Schwab Foundation. Their investments, educational and professional assistance throughout the world encourage developing social entrepreneurship while in Russia, this activity is not high developed.
In countries with innovation-based economy, the encouragement of innovation is fundamental. According to the results of the peer review Russia has negative values for the implementation of research and development while Switzerland was the undisputed world leader by the end of 2010 [4].

There, many reasons led to this situation, but the main ones are the following: difficulty to get access to new technologies for entrepreneurs, lack of an adequate system of state subsidies that allow young and growing companies to acquire new technologies.

The consequence of that is the low activity of Russian entrepreneurs in the high-tech sector, 
which is less than $4 \%$ while in Switzerland, the figure exceeded $10 \%$ (Fig. 2) [15].

It is interesting to notice the introduction of new technologies is the most active process. More than 6\% established entrepreneurs use new technologies in the manufacturing process (Fig. 3). Because of increasing competition in the market early entrepreneurs act in more aggressive manner and implement more actively advanced, and hi-tech technologies [14].

The use of high-tech technology is always associated with an increased risk for an entrepreneur so the role of the state as a party interested in the developing the economy can help the entrepreneur reduce the risk, including the government support measures, such as the subsidies tax credits and state guarantees.

\section{Conclusions and recommendations}

Forest resources should play an important role in the socio-economic development of Russia. Russia ranks 1st in the world with its stocks of for- est (Fig. 4) as the total stock of forests in the country exceeds 80 billion $\mathrm{m}^{3}$, it is about $20 \%$ of world reserves. Therefore improving the efficiency of the forest resources management in Russia should be one of the factors of economic growth.

Currently, forestry and forest-based industries do not play an important role in the economy of the country and occupies about 1\% of GDP. But the projected role of the UN FAO forestry sector in GDP can be raised to 3.5 percent, and investment to the sector can grow 5 times [16].

A key aspect in the economic development of the forestry and forest-based sector is the creation of an effective system of government support for entrepreneurship, and is the role of the financial instruments available and stable government policies is the main (Fig. 4) [4].

These measures of government support if their successful implementation will increase the share of Russian innovative entrepreneurship and transfer Russia to innovation development way with high-tech industries as the basement.

The study was sponsored by RHF within the research project «Nonlinear dynamics of the socio-economic systems: diagnostics, modeling, forecasting,» RHF project number 11-02-00531a.

\section{References}

1. Reynolds P., Autio E. (2005). Global Entrepreneurship Monitor: Data collection, design and implementation 1998-2003. Small Business Economics, 24 (3), 205-231.

2. Report of International trade center in 2012. Available at: http://www.intracen.org.

3. Innovation Index of Global Innovation Index. TOP-50. Available at: www.bloomberg.com

4. The Global Entrepreneurship Monitor. Graduate School of Management. St. Petersburg. 2010.

5. The concept of long-term socio-economic development of the Russian Federation for the period up to 2020. Approved by Order of the Government of the Russian Federation from November 17, 2008 number 1662-P.

6. «Report on the Global Competitiveness 2009-2010 Messrs. Available at: www.wefforum.org.

7. Information federal agencies to small and medium-sized enterprises. Available at: www.kmu.admin.ch

8. The total tax burden in \% of profit Source: PricewaterhouseCoopers AG in 2009.

9. Development priorities of the Russian timber industry, 2002. Study rating agency «Expert RA» Available at: http://www. raexpert.ru/researches/lesprom/lpk2002

10. Adult Population Survey (APS), report 2009

11. The Swiss Forest in Brief. Department of the Environment, Transport, Energy and Communications. Federal Office for the Environment FOEN. Available at: http://www.bafu.admin.ch/wald/01198/01199/index.html?lang=en

12. The Organization for Economic Cooperation and Development - OECD. Available at: http://www.oecd.org.

13. Federal Forestry Agency of the Russian Federation. Available at: http://www.rosleshoz.gov.ru.

14. Adult Population Surveys Russia (APS Russia), Report 2011.

15. Food and Agriculture Organization of the United Nations (FAO). Available at: http://www.fao.org/.

\section{Information about the authors}

Damary Roy (Genthod, Switzerland) - Ph. D. in Economics, Professor, President, Graduate Institute of Business and Management, INSAM (24 Chemin de Mont-Rose, Genthod, CH-1294, Switzerland, e-mail: r.damary@insamgeneva.org).

Shpak Natalya Anatolevna (Yekaterinburg, Russia) - Ph. D. in Economics, Vice-rector for Innovations and International Cooperation, Ural State Forest Engineering University (37 Sibirsky trakt, Yekaterinburg, 620100, Russia, e-mail: shpak@usfeu.ru). 